\title{
The Application of Process-Oriented Guided-Inquiry Learning (POGIL) Techniques through Lesson Study Activities in Educational Management Courses at English Education to Increase Learning Activity
}

\author{
Veny Agustini Prianggita ${ }^{1}$
}

${ }^{1}$ English Education Study Program of Teacher Training and Education Faculty, Universitas Mathla'ul Anwar Banten

\section{ARTICLE INFO}

Keywords:

POGIL

Lesson Study

Learning Activity

\begin{abstract}
Facing the industrial revolution 4.0, Indonesian citizens are challenged to be ready to feel some changes in many sectors including education sector. That is why Faculty of Teacher Training and Education of Mathla'ul Anwar University of Banten, a study programme which will prepare the graduates for industrial era 4.0 should start designing a learning process in order to create the graduates who are ready to face technology era that will be headed. This learning process innovation can be started by changing the learning paradigm from Teacher Centered Learning (TCL) to Student Centered Learning (SCL). One of technique that can be used is POGIL (Process-oriented guided-inquiry learning). It is a collaborative learning (cooperative, integrated inquiry, metacognitive). To make POGIL technique work optimally, it can be done by doing some learning activities of Lesson Study. Lesson study is an educator profession guiding model through learning assessment collaboratively and sustainably according to collegiality principals and mutual learning to improve the learning quality and learning community. Learning activities through the POGIL technique, are thought to be able to help improve the metacognition skills of English language education students, one of which is by seeing the results of the level of student activity while studying. This research is aimed to find out the student's activity by using POGIL technique through learning activities of Lesson Study. The research question of this article is how to increase student learning activities with the POGIL technique through LSLC? This research is descriptive statistical analysis. The populations in this research are 25 university students who take English Education Course. The data collecting technique was done by using questionnaire. After data collecting, normality testing was done by using Shapiro-Wilk testing (because the population is less than 100) with signification degree $\alpha=5 \%$, followed by $\mathrm{T}$ one-sample test.According to data processing result done by using SPSS version 25 , it is concluded that the average is 82,24 and deviation standard is 4,47 . Then the normality test is applied and we get Sig. for 0,549 , because the amount of Sig. is more than 0,05 so that data has normal distribution. Then $\mathrm{T}$ one-sample test is applied, and we get tcount $=1,734$ at the significant level $5 \%$. The number of ttable got from $t$ distribution table with $\mathrm{dk}=25$ is 1,708 . So, according to the result of data processing and $t$ distribution table, it is known that the score of tcount $=1,734>$ ttable $=1,708$ at the significant degree $5 \%$. It can be concluded that by POGIL technique application through Lesson Study activity, $80 \%$ students become more
\end{abstract}

\footnotetext{
1 Corresponding author's address: English Education Study Program of Teacher Training and Education Faculty, Universitas Mathla'ul Anwar Banten, Banten, Indonesia e-mail: venyagustinibaby@gmail.com
} 


\section{INTRODUCTION}

The universities in Indonesia are demanded to be able to anticipate the faster technology development happening in industrial revolution 4.0 era. Curriculum design and learning methods should be able to adapt with business climate which is growing up rapidly. Education service and industrial business are getting competitive and should follow the information and technology development. The changes in industrial revolution era are also influencing the human characteristics and work so that the skills needed changes rapidly. Our challenge that we will pass is how to prepare and map the work generations from education graduate who are surely ready to work, in other word, professional based on their skills in heading the industrial revolution 4.0. Appropriate with the industrial revolution development, education has to be able to facilitate the human and technology in order to work properly, to fit their own self in utilising the digital technology potential, personalised data, content from variety resources, and new humanity norm connected globally. A blueprint or the learning future should be applied from now on where the long life learning becomes the core of all. That is why, as a high education institution, Teacher Training And Education Faculty of Mathla'ul Anwar University of Banten as a unit had better prepare the graduates for industrial revolution era 4.0 and start to do the innovation in learning process.

In this time, in doing teaching, lecturer's focus is only limited in preparing for learning technique aspects. They are preparing for the learning material, learning method according to the material, and their own lesson plan. But the lecturers often ignore attitude aspect in teaching. For instance they seldom pay attention to the less potential students; they do not recognize the students who need more attention. They do not know why the students do mistake, they do not know which students who are not interested in the lesson, and they do not know why the students look bored in the learning process.

One of the alternative as strategic effort which will balance technique aspect and attitude aspect in learning process is by collaborating learning Process-oriented guided-inquiry learning (POGIL) technique through Lesson Study activity. POGIL technique is a collaborative learning (cooperative, integrated inquiry, metacognitive), where the research discovery result said that to achieve understanding and real learning, the learner should be active rearranging the information that is absorbed. This POGIL technique will change the teaching paradigm from Teacher Centered Learning (TCL) to Student Centered Learning $(S C L)$ where the students construct and discover knowledge with many approaches that will improve activity, creativity, critical thinking and collaborative. Even though the lecturer's role cannot be replaced by tools but only move from the learning source to be a facilitator.

In this research, there will be seen the students' learning activity in mastering learning material in English Education course through Lesson Study activity by using POGIL technique.

\section{Process- Oriented Guided- Inquiry Learning (POGIL) Technique}

POGIL technique was invented for the first time in Franklin and Marshall College State university of New York in 1994 by a group of professors led by Richard S. Moog cooperating with other Professor from Stony Brook University, David M.Hanson.

POGIL contains philosophy including strategy in teaching and learning. It is said correlatively with philosophy because it covers specific ideas about the characteristics of learning process and the result expected from it. Related to the strategy because this technique applies a method that is based on students' based learning and a structure which is consistently provides how the students study and achieve their learning result.

The three main components of POGIL are collaborative learning (in cooperative learning context), integrated inquiry, and metacognition. Integrated inquiry is an inquiry based learning where the lecturers provide the materials, tools, and the problems to solve. Next, the students arrange the equipment and procedures to solve the problem.

According to Warsono and Harianto, "this learning cycle consists of 3 phases, they are Exploration, Concept discovery or Concept design, and Application". As the other POGIL pillar, metacognition takes role related to "how we think, how we know and how we learn". Metacognition according to Flavell 1976 (in Warsono) "that refers to awareness and individual consideration related to the process and its cognitive strategy".

While according to Fogarty 1994 (Warsono, 2014), he defines metacognition generally as "an understanding and awareness about our own mind". As written by Schraw and Moshman, 1995, in Dale H. Schunk, 2012), "Students arrange metacognitive theory including knowledge and strategy that rusted will be effective in particular situations".

Dinsmore, Alexander \& Loghlin, 2008 in Dale H. Schunk, 2012) stated "metacognitive knowledge becomes important to achieve the effective of self-managed learning.". In this term, POGIL needs metacognition use to help the students in order to aware that they are in charge of their own learning. 


\section{Lesson Study}

Lesson Study is a guidance done by a team to improve learning quality. Considering in this millennium era, there are many students who can get knowledge by themselves through many kinds of resources, and in the other hand, in learning at the class, the lecturers sometimes are lack of method to make the students study

By the problem happening above, Lesson Study is the way for the lecturers to learn one another with caring concept in order to make saturation teaching not fully replaced by other learning source, but make it more innovative and find out the way to be a facilitator who can make students learn with vary methods and to find out discoveries and suggestions from others. Lesson Study activity consists of 3 main steps. They are: Plan, Do, and See.

\section{Plan}

Plan is a planning by analyzing which material will be discussed and Chapter Design making, the goals are: 1 . To map our comprehend about each material in a chapter; 2 . To concrete the material by discussing what essence will be given or learnt by the students each meeting in that chapter.

Then Lesson Design making, where the team tries to place as the students or the team tries to think as the students think about the material. The aim of Lesson Design making is to make learning process sequence starting from first activity, main, to evaluation and closing which in arranging it by using backward pattern. It is started from settling the last ability expected by the students that is used as a standard to help. It is usually the students who are in difficulty.

\section{Do and Learning Observation}

Do activity is done after the team finishes making Chapter Design and Lesson Design by demonstrating it in teaching learning process in the class by the model lecturers accompanied by the observer, in hope the scenario made can be used effectively, efficiently, and proportionally by the model lecturers. But, considering in the learning in the class, sometimes it has the obstacle. So if the scenario seems not correct, the lecturers can change it appropriate with the condition.

\section{Reflection and Redesign}

Reflection is an important step in Lesson Study. Ater plan making focusing on how the students learn and observe the real learning in the class in DO level, in SEE, the team will reveal comments about learning process seen from the students. The qualified SEE step indicated by how much and how deep we learn from the students. How much valuable discovery from that learning process. The qualified SEE step shows the quality of Lesson Study activity with Lesson Community caring concept.

In this redesign step, after the See step is done, it is continued to learning design remaking or Lesson Design for the next material in different class

\section{METHOD}

This research is descriptive statistic research aimed to find out the students learning activity improvement by POGIL technique through Lesson Study activity. This research is applied to the 25 students of semester VI at English Education Department Teacher Training And Education Faculty of Mathla'ul Anwar University of Banten.

As for the steps of doing this research are:

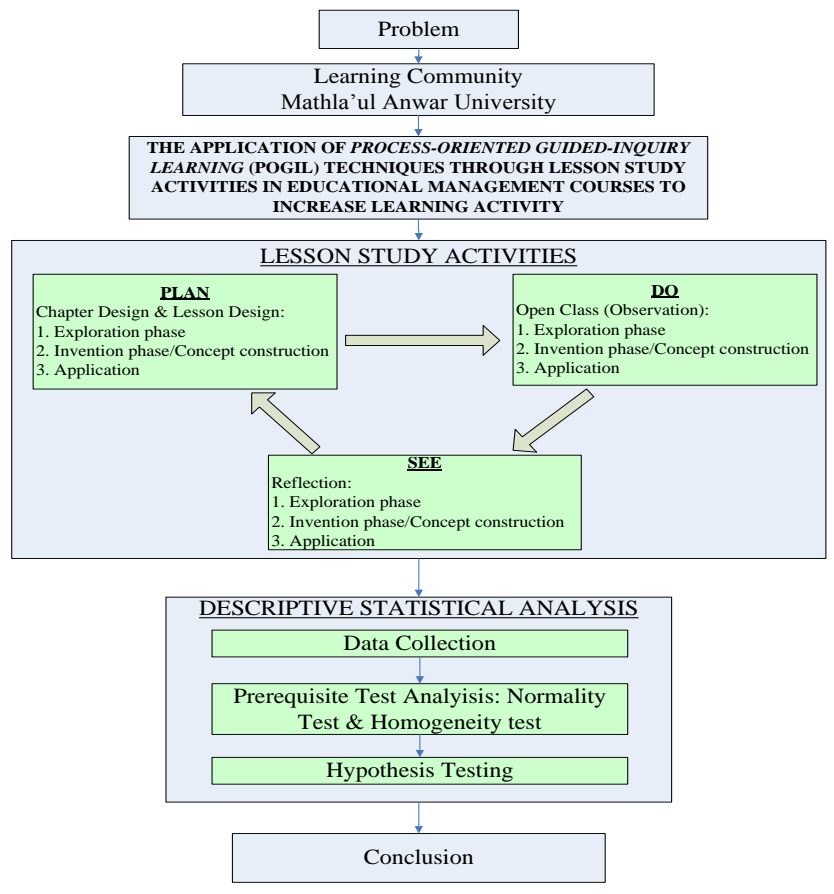

Picture 1.The Research Steps 
In this research, data collecting technique uses observation, documentation, and questionnaire. The questionnaire uses the linkert scale. The respondent decides agreement of a question/statement by choosing one of the choices provided. There are 5 choices:

Table 1. The Score of Likert Scale Positive Statement

\begin{tabular}{cc}
\hline Alternative Answer & Score \\
\hline Totally agree & 5 \\
\hline Agree & 4 \\
\hline Neutral & 3 \\
\hline Disagree & 2 \\
\hline Totally disagree & 1 \\
\hline
\end{tabular}

Some research instruments needed in this research are questionnaire, students' worksheet, and observation sheet. In questionnaire questions, there is an instrument test. The aim of this test is to measure the validity and reliability.

The data analysis got during the research has varied methods. Data description is done by descriptive analysis towards research variable. It is aimed to get the large view of students learning activity through questionnaire score applied after treatment.

The hypothesis in this research is described below:

- Zero Hypothesis $\left(\mathrm{H}_{0}\right)$

By applying POGIL technique through lesson study, less than $80 \%$ students are more active in learning process in the class.

- Alternative Hypothesis ( $\left.\mathrm{H}_{\mathrm{a}}\right)$

By applying POGIL technique through lesson study, more than $80 \%$ students are more active in learning process in the class.

Before hypothesis test, firstly, prerequisite test should be done. As for prerequisite test, it is used in this research including normality and homogeneity test. in this research, normality test is applied to all students' questionnaire score by using Shapiro-Wilk test. The test decision making and conclusion taking are taken from significant level $5 \%$ and are helped by using SPSS version 25 .

The test decision making and conclusion taking toward the normality test are done by significant level 0,05 . The decision is: if Xhitung $\geq$ Xtabel, it means that data distribution is not normal. Whereas if Xhitung $\leq$ Xtabel, it means that that data distribution is normal.

The Homogeneity test that will be used by the researcher in this research is by Levene test with the test decision making and conclusion taking taken from significant level $5 \%$ which is done by using SPSS version 25 .

The decision making and conclusion taking toward the normality test is applied to significant level $5 \%$. The decision is: if Xhitung $\geq$ Xtabel, it means that not homogeny. In the contrary, if Xhitung $\leq$ Xtabel, it means homogeny (Riduwan 2008: 119).

Data analysis after experiment is to examine the students' learning activity by using POGIL technique through Lesson Study activity. The requirements that should be fulfilled in this data by using $\mathrm{T}$ test show the difference of the result between two groups compared. If the activity data an students' learning result of experimental group and control group have normal distribution, two sample comparative, and the data is interval/ratio, then in its hypothesis testing ,it uses statistics independent sample t test.

The hypothesis test used in this research is the right side test. In this test, it occurs that if $t$ hitung is more than or equal with $(\geq) \mathrm{t}$ tabel, then Hois accepted and is declined (Sugiyono 2011:153).

If the result normality test analysis shows normal distributed data, then we use the independent sample $t$ test by using SPSS version 25. If the data examined is not normal distributed, then the last analysis is enough by using U Mann Whitney. Both $\mathrm{U}$ Mann Whitney formulas are used in counting because they will be needed to know which $\mathrm{U}$ is the smaller. That is what is used to test and to compare with $\mathrm{U}$ table.

\section{DISCUSSION}

Learning Design by using POGIL technique through Lesson Study activity

The main purpose of POGIL implementation is to help the students for mastering the learning content all together with improving essential learning skill, so the cycle from this learning consists of three steps, they are exploration, concept discovery and application. Those steps of activity are done by Lesson Study.

For the learning design in of English Education by POGIL technique through lesson study activity which is done by 3 learning cycles below:

\section{Cycle 1}

a) Plan: It was held on 30 April 2018. Plan was held in two teams by two people each. By POGIL technique in this first cycle, we planned on the students at the exploration step by giving case of "Management of School and Society Relationship" and "Management of Financial Education" ot the apperception. While for the material in the third cycle, "Education Leadership" was given quotation from some films entitle "Helen Keller" and "Tara Zamen Paar", 
where there would be many responses about learning media related to the cases and film clips given because the students would explore the discovery. For prediction at concept discovery level, the students would be guided by some questions on their worksheet to explore the concept, developing and understanding it. After they filled the worksheet based on the references, and then continuing to the next level that was application where there would be questions demanding the imaginative answer from the students.

b) Do: Do was held on Monday, 7 Mei 2018, at 13.30. In English Education course, there were 25 students and an observer in the learning process by POGIL technique. In this step, the students learned the material about "Management of School and Society Relationship" where in the apperception; the lecturer gave the case about parking area problem at the school environment, where everyone claimed that their arguments were right. By this problem, the students tried to explain or understand the learning media by proposing their own arguments, giving questions and statements. Occupied with the first case, the lecturer guided and pushed the students by questions on the worksheet which is obligated individually and worked in groups. By this way the students learned by trying to answer a sequence of lesson which is guiding them to explore concept representation, developing and understanding it. The questions proposed on the student worksheet are: "1. The aim of the school and society relationship is considered from two dimensions, school needs and society. Explain and give the example, 2. Explain by giving example of the principals of School and Society Relationship, 3. Explain the elements ad technique of School and Society Relationship". After the concept understood, the students were demanded to apply it with questions that allowed them to solve the problem: why is it needed to have School and Society Relationship?

c) See: See was held after learning process done in the class by 2 people, they were model lecturer and an observer. The main comment from model lecturer was "Lesson Study makes learning easier and the students seem more active by exploring and discovering knowledge through discussion. The lecturers only give the stimulus, by this kind of learning, it seems that the students have opportunity to enlarge their learning by conveying ides, questions, and new statements". The comment from the observer was "The students have studied actively by discussing with their group or others; the students also ask and answer the lecturer's questions. The learning material used by the students is varied start from hand phone using to module. Valuable lesson that can be taken from this observation is "all students are asked by guided and explored. And on the class conclusion, it is written by the student on the lecturer's laptop directly".

2. Cycle 2

a) Do: It was held on Monday, 14 Mei 2018 at 13.30, with 25 students of English Education course and an observer. In this step, the students learned by material "education financial management" where on apperception, the lecturer gave a case about corruption in education fund; there were many problems in education. By this kind of problem, the students tried to explain or understand about learning material by conveying their own arguments, proposing question and statement. Occupied with the first case, the lecturer guided and pushed the students by questions on the worksheet which is obligated individually and worked in groups. By this way the students learned by trying to answer a sequence of lesson which was guiding them to explore concept representation, developing and understanding it. The questions proposed on the student worksheet are: 1. Draw the sequence of school financial management, 2. Analysis school financial management. After the concept understood, the students were demanded to apply it with questions that allowed them to solve the problem: by the question, make the example of RKAS draught.

b) See: See was held after the learning process done by 2 people (technique guidance members). The main comment of model lecturer was "In the second Open Class, the students seem more confident; moreover the students who are already active and they can be peer tutor in a small group, not the big one". The main comment of the observer "the students seem active and some of them can be a tutor for their group even the large one, unfortunately, there is a student who seems not understand so the student's worksheet is still empty until the end of the class, even though the model lecturer has given some stimulus, maybe he is sick or tired".

3. Cycle 3

a) Do: It was held on Monday, 21 Mei 2018 at 13.30, with 25 students of English Education course and an observer. In this step, the students learned by material "education leadership management" where in the apperception; the lecturer gave the movie clips of "Helen Keller" and "Tarra Zamen Paar", where there were many problems in education because of the leader's misunderstanding. By this film, the students tried to explain and understand learning material by conveying their own arguments, proposing questions and statements. Occupied with the first case, the lecturer guided and pushed the students by questions on the worksheet which was obligated individually and worked in groups, By this way the students learned by trying to answer a sequence of lesson which was guiding them to explore concept representation, developing and understanding it. The question proposed on the student worksheet was: Explain the definition of education based on your opinion. After the concept understood, the students were demanded to apply it with questions that allowed them to solve the problem by imaginative question: If you are an education leader, what kind of leadership model will you use? Give the explanation.

b) See: See was held after learning process done in the class by 2 people. The main comment of model lecturer was "in the third cycle, the students got material about education leadership where they were asked to imagine being a leader and what model would be used. This material seemed a bit difficult by the students because before filling, they had to find out and differentiated each type of leadership. So the model lecturer gave much stimulus to the students by giving example. The comment from observer "The students seemed confused in leadership material but they still learned actively by using internet and discussing with their group or others even though there were some of them opening hand phone for WA". 


\section{Analysis of Descriptive Statistic}

In this research, there were 25 students. In its data collecting, it used 15 questions of questionnaire. From the collected data by using SPSS v. 25 we got the result as:

Descriptive Statistics

\begin{tabular}{lr|r|r|r|c|r|r} 
& N & Range & Minimum & Maximum & Mean & Std. Deviation & Variance \\
\hline Nilai & 25 & 25.34 & 69.33 & 94.67 & 82.2436 & 6.46771 & 41.831 \\
\hline Valid N (listwise) & 25 & & & & & & \\
\hline
\end{tabular}

According to data above, it can be described that the highest score is 94,67 and the lowest is 69,33 by average 82,24 . Where the deviation standard is 6,47 and variance 41,83 .

\section{Normality Test}

Next, from the questionnaire result, normality test which is requisite test of data analysis is applied. It is aimed at deciding the form to use in hypothesis test. Because the population in this research is less than 100, so we use Shapiro-Wilk. For Normality test by using Shapiro-Wilk we use SPSS v.25 by significant standard 0,05, the result is below:

\section{Tests of Normality}

\begin{tabular}{|c|c|c|c|c|c|c|}
\hline & \multicolumn{3}{|c|}{ Kolmogorov-Smirnov ${ }^{\mathbf{a}}$} & \multicolumn{3}{|c|}{ Shapiro-Wilk } \\
\hline & Statistic & df & Sig. & Statistic & df & Sig. \\
\hline Nilai & .127 & 25 & $.200^{\circ}$ & .966 & 25 & .549 \\
\hline
\end{tabular}

From normality test by using Shapiro-Wilk, it is obtained the Sig score as 0.549 . Because the significance score of normality test is more than 0,05 , it can be concluded that the variable is normal ditributes.

Hypothesis Test

Because the result of normality test shows normal distributed data, then hypothesis test by using independent sample $t$ test, by SPSS 25 gets the result below:

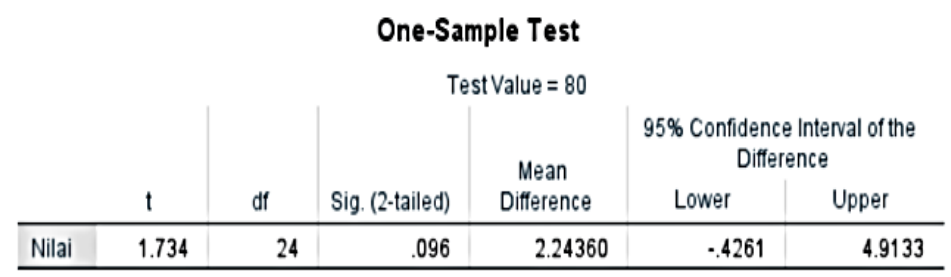

The result of T test statistics analysis counted by using independent sample $t$ test in SPSS 25 , concluded the students learning activity data with tcount $>$ table, $1,734>1,708$, then $\mathrm{H}_{0}$ is declined and $\mathrm{H}_{\mathrm{a}}$ is accepted. So that according to $\mathrm{T}$ test result, it shows that by applying POGIL technique through Lesson Study, there are more than $80 \%$ students become more active in learning process in the class.

\section{CONCLUSION}

This research is a test of POGIL learning technique application through Lesson Study activity to find out the level of students learning activity. $80 \%$ the students have studied actively by discussing either with their group or others; the students also ask and answer the lecturer's questions, the learning materials used by the students are varied starting from hand phone using to module. Valuable lesson that can be taken from this observation is "all students are asked by guided and explored. And on the class conclusion, it is written by the student on the lecturer's laptop directly".

\section{REFERENCES}

Dirjen SDID IPTEK DIKTI. Pedoman Panduan Bimtek Dosen Kategori Lesson Study Tahun 2018.

Ibrohim. (2018). Teknik Perencanaan, Pelaksanaan dan Refleksi Pembelajaran Dalam Lesson Study. Materi Dalam Bimtek LSLC Kemenristekdikti

Riduan. (2008). Dasar-Dasar Statistika. Bandung: Alfabeta.

Schunk, Dale. H. (2012). Learning Theories An Educational Persfektive. Yogyakarta: Pustaka Pelajar.

Sugiyono. (2014). Metode Penelitian Kuantitatif, Kualitatif dan R\&D. Bandung: Alfabeta.

Warsono, (2014). Hariyanto. Pembelajaran Aktif. Bandung: PT: Remaja Rosdakarya. 